\title{
Simulation Model for Cyber Crime Reduction
}

\author{
Bhanu Sahu \\ AISECT University \\ Bhopal
}

\author{
Deepti Maheshwari \\ AISECT University \\ Bhopal
}

\author{
Neeraj Sahu \\ AISECT University \\ Bhopal
}

\begin{abstract}
We want to reduce cyber crime using simulation. The Experimental Results show how user behavior based model help to reduce cyber crime. User behavior prediction and most probable its nature is show cyber crime probability is high and low. We use simulation reduce cyber crime. Outcomes are more efficient and accurate.
\end{abstract}

\section{Keywords}

User behavior based modeling, Behaviour, Cyber Crime reduction, Computer Simulation.

\section{INTRODUCTION}

There are many types of user behavior where judgments authorities do not able to decide take decision with different new methods of user behavior because this type user behavior is first time found. User behavior basic classification is show in figure 1 .

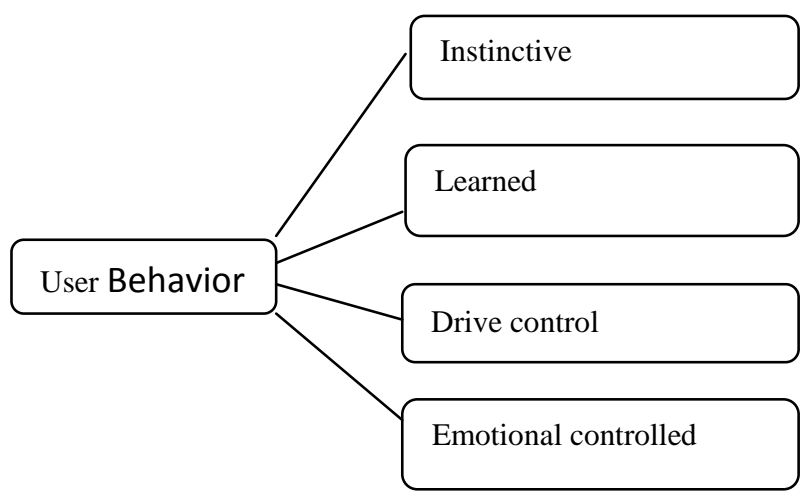

Figure 1: Classification of User behavior

In 1975 Baldwin, J. gave British areal studies of grime: An assessment[3].

In 1976 Baldwin, J., \& Bottoms, A. E. gave The urban criminal: A study in Sheffield[4].

In 1993 Brantingham, P., \& Brantingham, P. gave Environment, routine, and situation:Toward a pattern theory of crime and R. Clarke \& M. Felson gave Routine Activity and rational choice[8],Brown, B. B., \& Bentley, D. L. gave Residential burglars judge risk: The role of territoriality[12].

In 1994 Beavon, D. J. K., Brantingham, P. L., \& Brantingham, P. J. gave The influence ofstreet networks on the patterning of property offenses[5].

In 1997 Axelrod, R. gave Advancing the art of simulation in the social sciences and R.Conte, R. Hegselmann, \& P. Terna gave Simulating social phenomena [2].

In 1997 Bowers, K., \& Hirschfield, A. gave Exploring the link between crime and disadvantage in north-west England: An analysis using geographical information systems[6].

In 2003 Brailsford, S., \& Schmidt, B. gave Towards incorporating human behaviour in models of health care systems: An approach using discrete event simulation[7].
In 2003 Brantingham, P. L., \& Brantingham, P. J. gave Computer simulation as a tool for environmental criminologists[9].

In 2005 Brantingham, P., Glasser, U., Kinney, B., Singh, K., \& Vajihollahi, M. gave A computational model for simulating spatial aspects of crime in urban environments[10].

In 2008 Brantingham, P., Glässer, U., Jackson, P., Kinney, B., \& Vajihollahi, M. gave Mastermind: Computational modeling and simulation of spatiotemporal aspects of crime in urban environments[11].

In 2009 Al-Ahmadi, K., Heppenstall, A. J., Hogg, J., \& See, L gave A Fuzzy Cellular Automata Urban Growth Model (FCAUGM) for the City of Riyadh, Saudi Arabia[1].

The paper is shows in Section-I described the introduction and review of literatures. In Section-II, Calculation for reduction Cyber crime is described. In Section-III, Methodology of Cyber crime is described. In Section-IV, Experimental results are described.

\section{CALCULATIONS FOR REDUCTION CYBER CRIME}

Table 1 show \% of cyber crime reduction in first top 20 countries United States of America, China, Germany, Britain, Brazil, Spain, Italy, France, Turkey and Poland, India, Russia, Canada, South Korea and Taiwan, Japan, Mexico, Argentina, Australia and Israel.

Table 1: Cyber crime Reduction Percentages in top 20 countries

\begin{tabular}{|c|c|}
\hline Countries & $\begin{array}{c}\text { Cyber crime Reduction } \\
\text { Percentages }\end{array}$ \\
\hline United States of America & 16 \\
\hline China & 5 \\
\hline Germany & 7 \\
\hline Britain & 4 \\
\hline Brazil & 5 \\
\hline Spain & 5 \\
\hline Italy & 5 \\
\hline France & 4 \\
\hline Turkey & 4 \\
\hline Poland & 5 \\
\hline India & 6 \\
\hline Russia & 3 \\
\hline Canada & 5 \\
\hline South Korea & 3 \\
\hline Taiwan & 2 \\
\hline Japan & 2 \\
\hline
\end{tabular}




\begin{tabular}{|c|c|}
\hline Mexico & 3 \\
\hline Argentina & 2 \\
\hline Australia & 2 \\
\hline Israel & 1 \\
\hline All Other Countries & 11 \\
\hline
\end{tabular}

\section{METHODOLOGY}

\subsection{The Users}

The model used by users. Money need level is depend on user to do cyber crime. Intensity function shows need, environmental influences. Intensity analyzer show work, behavior and no action with action planner.N use for Need, EI use for Environmental Influences, OI use for Others Influences in $\mathrm{F}$ function.

\subsection{The Model Environment}

The model environment user behavior in house, road, work place, empty space. $\mathrm{H}_{1}$ to $\mathrm{H}_{5}$ house, $\mathrm{R}_{1}$ to $\mathrm{R}_{6}$ roads, $\mathrm{W}_{1}$ and $\mathrm{W}_{2}$ workplaces and $E_{1}, E_{2}, E_{3}$ are empty space.

\subsection{Model Experimentation}

The model will be applied to testing out crime theories and the effectiveness of varying crime reduction strategies. The following experiments will performed.

\subsubsection{Control behavior: The model use to control} behavior of users.

\subsubsection{Different types of users: The model used by} different type of users.

3.3.3 Target security: verification of sender's message as know authentication and give rights to access users as know authorization.

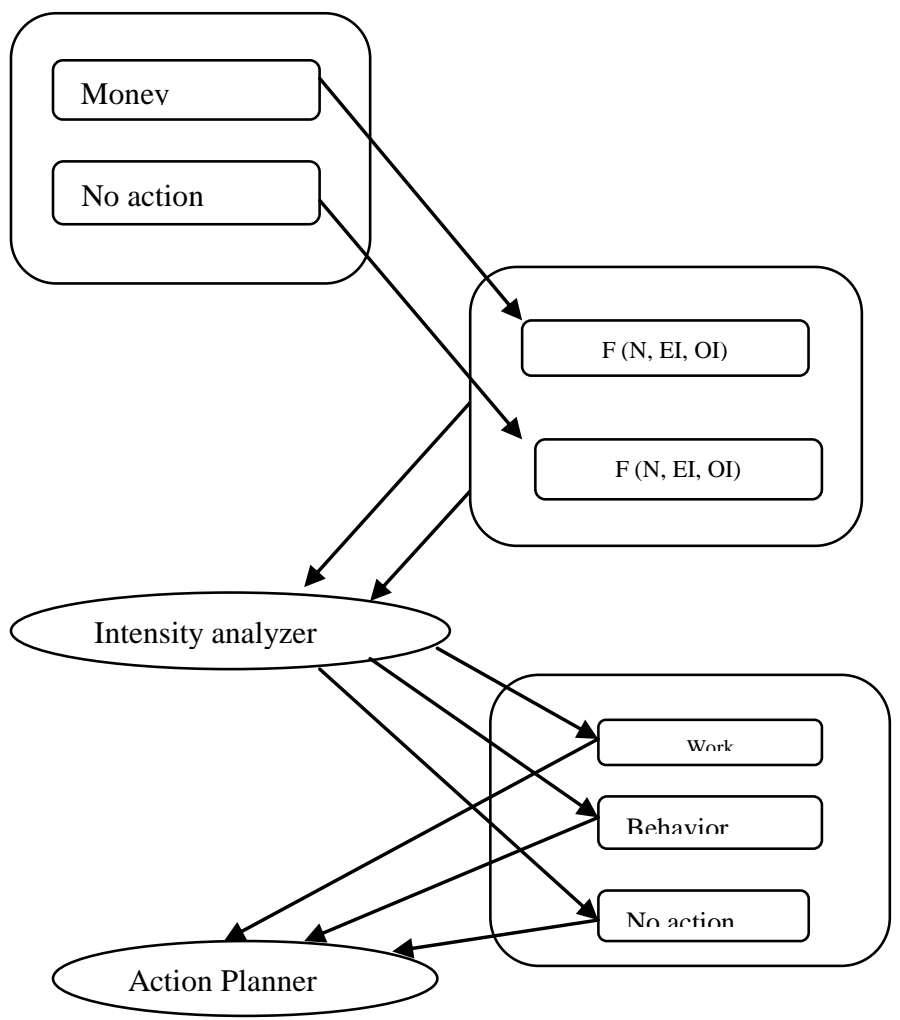

Figure 2: Users needs and behavior .The users need and how their intensities determine the behavior of the users.

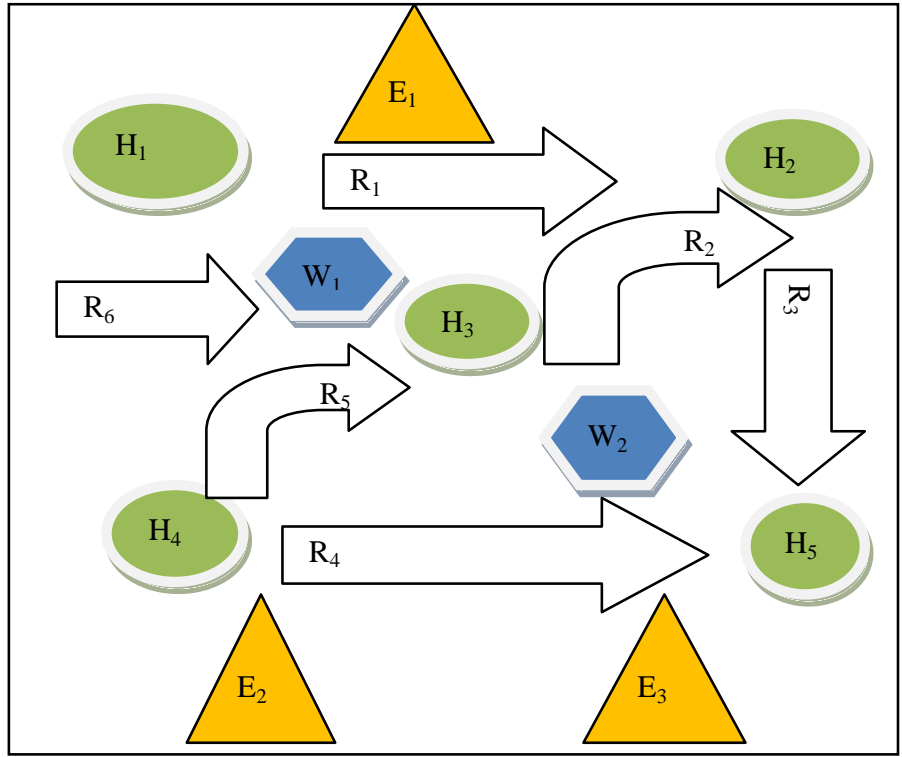

Figure 3: User behavior model environment

\section{EXPERIMENTAL RESULTS}

Cyber crime reduction Percentages in top 20 countries is show in graphical format Figure 4 to 7 show \% of cyber crime reduction.

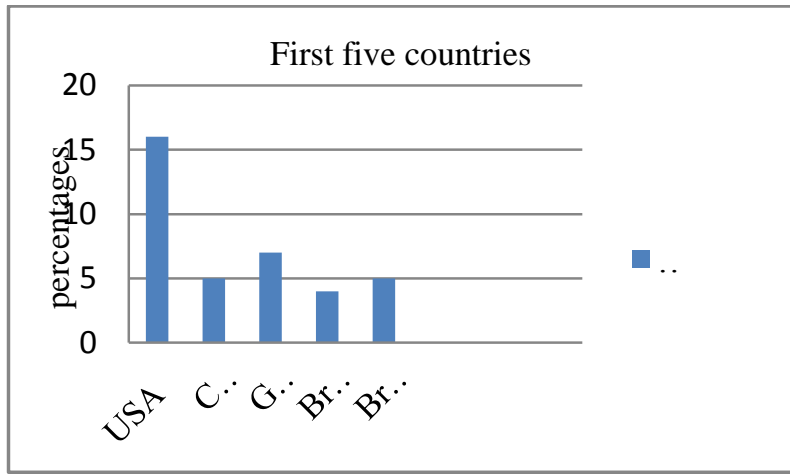

Figure 4: Cyber crime reduction $\%$ in first five top countries

Figure 4 show $\%$ of cyber crime reduction in first five top countries United States of America, China, Germany, Britain, and Brazil.

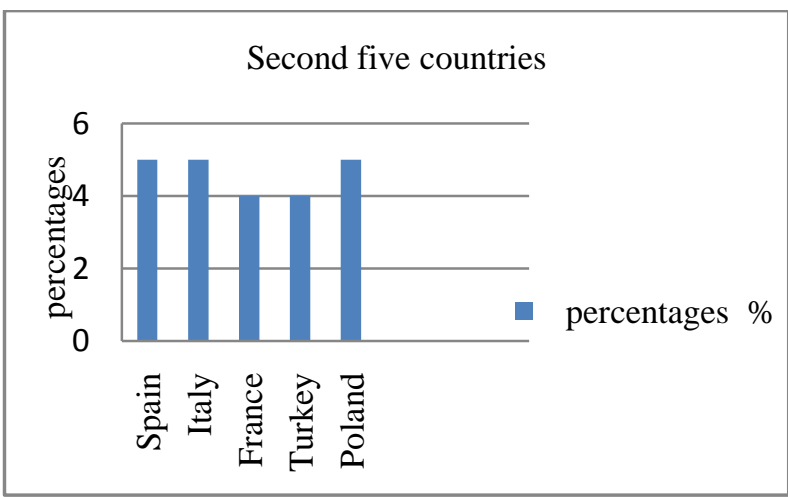

Figure 5: Cyber crime reduction \% in second five top countries

Figure 5 show $\%$ of cyber crime reduction in second five top countries Spain, Italy, France, Turkey and Poland. 


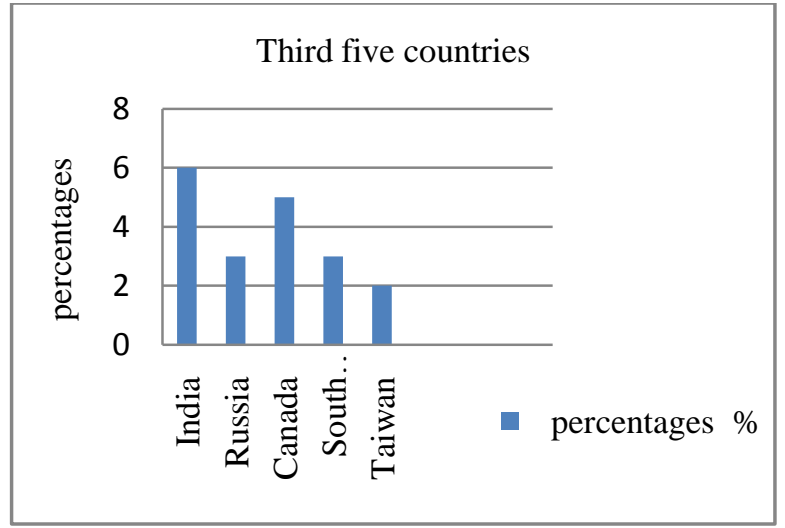

Figure 6: Cyber crime reduction $\%$ in third five top countries

Figure 6 show \% of cyber crime reduction in third five top countries India, Russia, Canada, South Korea and Taiwan.

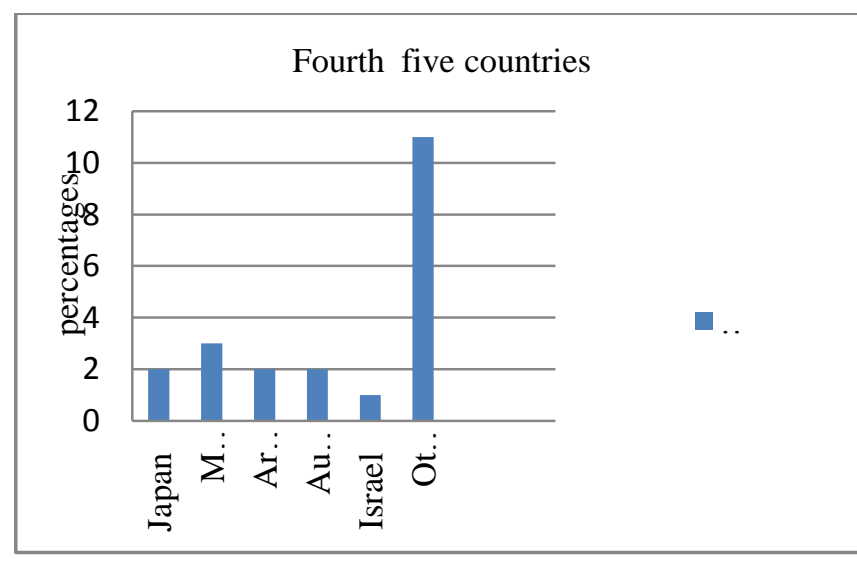

Figure 7: Cyber crime reduction $\%$ in fourth five top countries

Figure 7 show $\%$ of cyber crime reduction in fourth five top countries Japan, Mexico, Argentina, Australia and Israel.

\section{ACKNOWLEDGMENTS}

Our thanks to the Dr. Deepti Maheshwari who have contributed towards development of the Model.

\section{REFERENCES}

[1] Al-Ahmadi, K., Heppenstall, A. J., Hogg, J., \& See, L. (2009). A Fuzzy Cellular Automata Urban Growth Model (FCAUGM) for the City of Riyadh, Saudi Arabia. Part 1:Model structure and validation. Applied Spatial Analysis and Policy, 2(1), 65-83.

[2] Axelrod, R. (1997). Advancing the art of simulation in the social sciences. In R.Conte, R. Hegselmann, \& P.
Terna (Eds.), Simulating social phenomena (pp. 21-40). Berlin: Springer-Verlag.

[3] Baldwin, J. (1975). British areal studies of grime: An assessment. The British Journalof Criminology, 15(3), 211-227.

[4] Baldwin, J., \& Bottoms, A. E. (1976). The urban criminal: A study in Sheffield. London:Tavistock Publications.

[5] Beavon, D. J. K., Brantingham, P. L., \& Brantingham, P. J. (1994). The influence ofstreet networks on the patterning of property offenses. In R. V. Clarke (Ed.).Crime prevention studies (Vol. 2). New York: Criminal Justice Press

[6] Bowers, K., \& Hirschfield, A. (1999). Exploring the link between crime and disadvantage in north-west England: An analysis using geographical information systems. International Journal of Geographical Information Science,13(2), 159-184.

[7] Brailsford, S., \& Schmidt, B. (2003). Towards incorporating human behaviour in models of health care systems: An approach using discrete event simulation. European Journal of Operational Research, 150(1), 1931.

[8] Brantingham, P., \& Brantingham, P. (1993). Environment, routine, and situation:Toward a pattern theory of crime. In R. Clarke \& M. Felson (Eds.), Routine activityand rational choice. Advances in criminological theory (Vol. 5). New Brunswick,NJ: Transaction Publishers.

[9] Brantingham, P. L., \& Brantingham, P. J. (2004). Computer simulation as a tool for environmental criminologists. Security Journal, 17(1), 21-30.

[10] Brantingham, P., Glasser, U., Kinney, B., Singh, K., \& Vajihollahi, M. (2005a). A computational model for simulating spatial aspects of crime in urban environments. In 2005 IEEE international conference on systems, man and cybernetics (Vol. 4, pp. 3667-3674).

[11] Brantingham, P., Glässer, U., Jackson, P., Kinney, B., \& Vajihollahi, M. (2008).Mastermind: Computational modeling and simulation of spatiotemporal aspects of crime in urban environments. In L. Liu \& J. Eck (Eds.), Artificial crime analysis systems: Using computer simulations and geographic information systems (pp. 252-280). IGI Global.

[12] Brown, B. B., \& Bentley, D. L. (1993). Residential burglars judge risk: The role of territoriality. Journal of Environmental Psychology, 13, 51-61. 